\title{
Özerklik Teorisi ve Sosyal İlişki Gereksinimi Ölçeğinin Türkçeye Adaptasyonu
}

\author{
Dr. M. Hülya Ünal-Karagüven ${ }^{{ }^{*}}$ \\ Dr. Mukadder Karaman-Ekșioğlu \\ Çiğdem Gül ${ }^{3}$
}

Geliş tarihi: 06.12.2019

Kabul tarihi: 28.01.2020

\section{Atıf bilgisi: \\ IBAD Sosyal Bilimler Dergisi \\ Sayı: $6 \quad$ Sayfa: $366-377$ \\ Yıl: 2020 Dönem: Kıs}

This article was checked by intihal.net. Similarity Index 27\%

Bu makalede araştırma ve yayın etiğine uyulmuştur.

\footnotetext{
${ }^{1}$ Marmara Üniversitesi, Türkiye mhulya@marmara.edu.tr ORCID ID 0000-0002-6375-8930

2 Marmara Üniversitesi, Türkiye mkaraman@marmara.edu.tr ORCID ID 0000-0001-7261-3824

${ }^{3}$ Marmara Üniversitesi, Türkiye cigdem.gul@marmara.edu.tr
} ORCID ID 0000-0001-9201-3682

* Sorumlu yazar
ÖZ

Sosyal yönden bağlantı kurma, diğer insanların sevgi ve saygısını kazanma ihtiyac1 temel bir gereksinim olarak kabul edilmektedir. Bu konu Özerklik Teorisinde incelenmiş ve ilişkililik (relatedness) ya da sosyal ilişki kurma gereksinimi olarak tanımlanmıştır. Aynı teori kapsamında sosyal ilişki kurma gereksinimi düzeyini belirleme yönelik "The Need for Relatedness Scale" (NRS10) adıyla bir ölçek geliştirilmiştir. Ölçek Kanada'da İngilizce olarak geliștirilmiștir. Amacı, okul ve benzeri iș ortamlarında yetișkinlerin sosyal ilișki kurma gereksinimi düzeyini belirlemektir. Konuyla ilgili Türkçe çalışmalar yapabilmek için kullanımı kolay, geçerlik ve güvenirliği tatminkâr ölçme araçlarına ihtiyaç duyulmaktadır. Bu çalıșmanın amacı önce Özerklik Teorisini sunmak daha sonra bu teori temelinde geliştirilen NRS-10 ölçeğinin Türkçeye adaptasyonunu sağlamaktır. NRS-10 on maddeden oluşan iki boyutlu bir ölçektir. Türkçe eşdeğerlik ön çalışması, İngilizce öğretmenliği son sınıf öğrencilerden oluşan 90 kişilik bir grupla yapılmış ve Türkçe form "Sosyal İlişki Gereksinimi Ölçeği" (SİGÖ-10) olarak adlandırılmıştır. Çalışma grubu toplamda 390 üniversite son sınıf öğrencilerinden oluşmuştur. SİGÖ-10 ile birlikte bir anket formu ve Çevresel Destek Ölçeği kullanılmıștır. Hipotez testi, yapısal faktör analizi, iç tutarlılık katsayısı ve korelasyon teknikleri kullanılmıştır. Bulgular NSR-10'un Türkçe formunun yetişkinler arasında sosyal ilişki ihtiyacı düzeyini belirlemek amacıyla kullanılabilecek bir ölçek olduğunu göstermiştir. Ölçek Türkçe çalıșmalarda veri toplamak amacıyla kullanılabilir. Konu ile ilgili benzer çalışmaların yapılması önerilmiştir.

Anahtar Kelimeler: Özerklik Teorisi, İlişkililik, Sosyal ilişkili gereksinimi ölçeği. 
Self Determination Theory and the Adaptation of Need for Relatedness Scale (NRS-10) To Turkish

\author{
Dr. M. Hülya Ünal-Karagüven ${ }^{1^{*}}$ \\ Dr. Mukadder Karaman-Ekşioğlu ${ }^{2}$ \\ Çiğdem Gül ${ }^{3}$
}

First received: 06.12.2019

Accepted: 28.01.2020

\title{
Citation:
}

IBAD Journal of Social Sciences

Issue: $6 \quad$ Pages: 366-377

Year: $2020 \quad$ Session: Winter

This article was checked by Turnitin. Similarity Index $27 \%$

\footnotetext{
${ }^{1}$ Marmara University, Turkey, mhulya@marmara.edu.tr ORCID ID 0000-0002-6375-8930

2 Marmara University, Turkey, mkaraman@marmara.edu.tr ORCID ID 0000-0001-7261-3824

3 Marmara University, Turkey, cigdem.gul@marmara.edu.tr
} ORCID ID 0000-0001-9201-3682

* Corresponding Author

\begin{abstract}
The need to establish social connections and gain the love and respect of other people is considered as a fundamental requirement. This issue has been examined in the Self Determination Theory (SDT). According to SDT relatedness is a basic need for individuals. A scale was developed in English on the tenets of selfdetermination theory to evaluate the need of relatedness levels of individuals. This scale was named as "Need for Relatedness Scale". In order to work on this subject in Turkish studies, valid and reliable Turkish instruments are needed. The aim of this study was to examine Self Determination Theory and adapt Need for Relatedness Scale (NRS-10) to Turkish. The scale determines the relatedness levels of adults in school and similar work environments. NRS-10 is a twodimensional scale consisting of ten items. The Turkish equivalence study was conducted with a group of 90 senior students from English department of the foreign language school. Turkish form of the NRS-10 was named as the "Sosyal İlişki Gereksinimi Ölçeği”" (SİGÖ-10). The study group consisted of totally 390 seniors. In addition to the Turkish version of NRS-10 a questionnaire and Turkish version of the Communal Mastery Scale were also used. Hypotheses testing and confirmatory factor analyses methods were used. Cronbach's alpha and item-total correlation coefficients were also calculated. As a result of the findings, it was determined that the SİGÖ-10 can be used to collect data in Turkish studies. Similar studies have been proposed.
\end{abstract}

Key words: Self Determination Theory, Relatedness, Need for Relatedness Scale. 


\section{GİRIŞ}

Sosyal yaşamın, arkadaşlık, dostluk ilişkisinin, sosyal ilişkinin insan yaşamında önemli olduğu bilinen bir geçektir. Sosyal ilişkinin sözlük anlamı; iki kişi arasındaki karşılıklı ilgi, bağ, münasebet, temas olarak belirlenmiştir (www.tdk.gov.tr). Birey, bir insan grubu içinde yaşamak ve bu insanlarla iletişim kurmak ihtiyacı içinde olan sosyal bir varlıktır.

Sosyal ilişkide olma ihtiyacı bireyin başkaları tarafından bağlanma, sevilme ve değer verilmesi ile ilgilidir. Böyle bir deneyim, zorlukların üstesinden gelmek için gerekli olan, aynı zamanda hedeflere ulaşma olanağı sağlayan güvenlik duygularıyla ilişkilidir. Örneğin; aileler çocuklarına, başka çocuklarla birlikte olmanın sağladığı duygusal destek ve sıcaklık gibi okuldaki motivasyon için gerekli psikolojik kaynakların sağlanmasında da yardımcı olurlar (Grolnick ve Ryan, 1989; Grolnick, Friendly, Bellas. 2009). Sosyal ilişkili olma, motivasyon konusu ile yakından ilgilidir. Psikolojik iyi oluş, hayattan zevk alma, yüksek motivasyona sahip olma açısından kişilerin sosyal yönden ilişki içinde olması önem taşımaktadır (Deci, Ryan, 2010a; Deci, Ryan, 2010b). Sosyal ilişki gereksinimi önem kazanmakta ve güncel çalışmalara konu teşkil etmektedir (Minnaert, Boekaerts, ve Brabander, 2007; Niemiec, ve Ryan, 2009; Ormrod, 2018). Gerek çocukluk ve ergenlik döneminde, gerekse iş ortamında sosyal ilişki gereksinimi konusu pek çok çalışmaya konu olmuştur (Alderfer, 1972, Beyazkürk, Anlıak, ve Dinçer, 2007). Sosyal ilişki, sosyal bağlamda diğer insanlarla güvenli bir şekilde bağlantı kurma hissini ve "sevilmek ve sayılmak, sevgi ve saygıya değer olma" ihtiyacını kapsar (Connell ve Wellborn, 1991, S.51). Sosyal ilişkili kurma ve bir gruba ait olma gereksinimi bu güne kadar farklı teorilerde incelenmiştir (Maslow, 1943; Alderfer, 1972; Deci ve Ryan, 1985).

Maslow'un İhtiyaçlar Hiyerarşisi Teorisine göre gereksinimler şu şekilde kategorize edilmiştir: birinci sırada temel fizyolojik gereksinimler (nefes, besin, su, cinsellik, uyku, denge, boşaltım), ikinci sırada güvenlik gereksinimi (vücut, iş, kaynak, etik, aile, sağlı, mülkiyet güvenliği), üçünü sırada ait olma, sevgi, sevecenlik gereksinimi (arkadaşlık, aile, cinsel yakınlık). Bu gereksinimleri dördüncü sırada saygınlık gereksinimi (kendine saygı, güven, başarı, diğerlerinin saygısı, başkalarına saygı) ve son olarak beşinci sırada kendini gerçekleştirme gereksinimi (erdem, yaratıcılık, doğallık, problem çözme, önyargısız olma, gerçeklerin kabulü) takip eder (Maslow, 1943; Maslow 1970; Wahba, Bridwell, 1976). Görüldüğü gibi, ait olma gereksinimi (sosyal gereksinimler) temel fizyolojik gereksinimlerden ve güvenlik gereksiniminden sonra en önemli görülen üçüncü gereksinimdir. İnsan bir gruba dâhil olma ve onlarla sosyal ilişki kurma ihtiyacı içindedir.

Sosyal gereksinimler Maslow'un (1943) İhtiyaçlar Hiyerarşisi Teorisinden sonra Alderfer'in (1972) ERG Teorisine Konu olmuştur. Bu teoride; ikinci sırada sosyal ilişskili olma ihtiyacı yer alır ve Maslow'un ait olma ve sosyal gereksinimler düzeyine tekâmül eder. İnsan bir gruba dâhil olma ve onlarla yakınlık kurma ihtiyacı içindedir.

Sosyal açıdan ilişkili olma gereksinimi daha sonra 1985 yılında Edward Deci ve Richard Ryan tarafından geliştirilen Özerklik Teorisi (Self Determination Theory-SDT) içinde de yer almıştır. Bu teoride insanların sosyal yönden bağlantı kurma, diğer insanların sevgi ve saygısını kazanma ihtiyacı temel bir gereksinim olarak kabul edilmektedir. Motivasyonu açıklamaya yönelik kapsamlı bir teori olan Özerklik Teorisi, Türkçe çalışmalarda Öz Belirleme Teorisi ve Öz Yeterlilik Teorisi adıyla yer alır. Bu teori; motivasyonun tek bir yapı göstermediğini öne sürmesi ve özerkliğin önemini vurgulaması nedeniyle motivasyon konusuna farklı bir bakış açısı getirmiştir. Özerklik Teorisine göre, sosyal ilişki olma gereksinimi, sosyal bağlamda diğer insanlarla güvenli bir şekilde bağlantı kurma hissini ve "sevgi ve saygiya değer ve değerde olma" ihtiyacını kapsar (Connell ve Wellborn, 1991, S.51). Teori ile ilgili olarak yayınlandığı 1985 yılından günümüze kadar pek çok çalışma yapılmıştır (Deci ve Ryan, 1985, 2000; 2002; 2010; 2010a; 2014; 2016). Çalışmalar halen devam etmektedir.

Özerklik Teorisine göre insan doğduğu andan itibaren çevre ile karşılıklı (diyalektik) bir ilişkiye girer. İnsan çevresi tarafından desteklensin veya desteklenmesin doğduğu andan itibaren içsel bir uyarılma ve öğrenme isteğine sahiptir (Deci, 1975; Deci ve Ryan, 1985, 2000; Ryan ve Deci, 2000; 2017; 2019). Bu doğal dürtü veya içsel motivasyonun derecesi bireyin gereksinimlerinin sosyal çevre içinde giderilmesi derecesine bağlı olarak gerçekleşir. Yani, bu çevresel gereksinimlerin giderilmesi içsel motivasyon için gerekli bir önkoşuldur. İnsan sosyal çevre içinde üç doğal veya temel psikolojik ihtiyacı karş1lamaya 
çalışır. Bu temel gereksinimler karşılandığında psikolojik iyi oluş hali olumlu etkilenirken, karşılanmadığında olumsuz etkilenir. İçsel motivasyonu etkileyen bu gereksinimler; özerklik (autonomy), yeterlik (competence) ve sosyal ilişki (ilişkili olma) (relatedness) şeklinde ifade edilir (Ryan ve Deci, 2000; 2017; 2019). Bu gereksinimleri şu şekilde açıklamak mümkündür.

Özerklik (autonomy): İlk temel psikolojik gereksinim özerkliktir. Özerklik; bireyin tercihlerini dışsal etkilerden bağımsız olarak yapabilmesidir (Deci ve Ryan, 1985; Ryan ve Deci, 2000; 2017; 2019). Kişinin kendi adına karar verebilme ve davranışlarını kontrol edebilmesini hissetmesi olarak kabul edilir. Yani birey davranışlarını kendi isteği ile başlatıp sürdürüyorsa ve davranışın taşıdığı değeri benimsiyorsa özerk olduğu söylenebilir. Bu kişiler kendi amaçlarını tanımlayabilir ve amaçlara ulaşmak için sorumluluk alabilir, sorumluklarını yerine getirebilirler. Böylece birey yaşamı üzerinde kontrol sağlayabilir ve hayatını kendi düzenlemeyi başarabilir (Deci ve Ryan, 1985, 2000; Deci, Vansteenkiste, 2004). Özerkliğin aileden ayrılma ve bağımsızlaşma anlamına gelmediği ve evrensel bir yapıda olduğu yapılan kültürler arası çalışmalarla tespit edilmiştir (Schwartz, 1994; Vansteenkiste, Zhou, Lens, ve Soenens. 2005; Kağıtçıbaşı, 2005). Yapılan çalışmalar bu durumun evrensel nitelikte olduğunu göstermektedir

Yeterlik (competence-yetkinlik): Bu teoride ikinci temel psikolojik gereksinim yeterliktir. Türkçede yetkinlik olarak da ifade edilebilir. Yeterlik; bireyin yaptığı aktivitelerde yeteneklerini kullanabilmesi ve geliştirebilmesidir (Deci ve Ryan, 1985; Ryan ve Deci, 2000). Yeterlik bireyin yaşadığ çevrede etkin bir biçimde eylemde bulunabilmesi ve çevresiyle başa çıkmada kendini yeterli hissetmesidir (Deci ve Ryan, 1985, 2000; Deci, Vansteenkiste, 2004). Bu bireyler içsel bir motivasyon ile kendilerini aşmaya çalışır, çevrelerini keşfetmek ve etkilemek isterler.

Sosyal İlişki (relatedness-ilişkililik): Özerklik teorisinin son temel gereksinimi ilişkili olmadır, aslında Türkçe karşılığını "ilişkililik" olarak da tanımlamak mümkündür. Genelde ilişkili olma, çevresindeki bireylerle yakın ilişkiler kurmak, iletişime geçmek gibi gereksinimleri ifade eder. Kısaca, bireyin çevresinde değer verdiği insanlarla etkileşimi ve bu etkileşim sırasında kendini topluluğun bir parçası olarak hissetmesidir (Ryan ve Deci, 2000). İlişkili olma ihtiyacını tatmin etmek için bireyler yakın ve kaliteli ilişkiler kurmaya, destek ve güven veren bağlara sahip olmaya çalışırlar. Sosyal ilişki ihtiyacının giderilmesi içselleştirme sürecini kolaylaştırır. Bireyler kendi değer yargıları ve yaşantıları ile benzerlik gösteren kişiler ile yakınlık kurarak sosyal açıdan ilişkili olma duygularını içselleştirirler (Deci ve Ryan, 1985, 2000; Deci, Vansteenkiste, 2004; Deci, Ryan, 2010a; Deci, Ryan, 2010b). Diğer bir deyişle bu ihtiyaç sosyal yapı içinde diğer insanlarla sağlıklı ilişkiler kurmanın önemini vurgular.

Özerklik Teorisi'ne göre bu üç özellik insan davranışlarını kontrol eden temel unsurlardır. Bu gereksinimlerin giderilme derecesine bağlı olarak, çevre, gelişim süreci boyunca, içsel motivasyonu güçlendirir ya da zayıflatır (Deci ve Ryan, 2000). Bu gereksinimler ile çevrenin etkileşimi sonucu üç faklı motivasyon türü oluşur. Bunlar sırasıyla; içsel motivasyon; bir aktiviteyi sadece zevk almak ve tatmin olmak için sürdürme dürtüsü, dışsal motivasyon; bir aktiviteyi zorunluluk olmadan, veya bir amaca ulaşmada araç olarak sürdürme dürtüsü ve motivasyonsuzluk ise; bir aktiviteyi, davranışları ile aktivite arasında olası bir ilişki kuramama nedeniyle yürütme niyet veya dürtüsünün olmamasıdır (Deci ve Ryan, 1985; 2000). Bu teoride motivasyonun düzeyi yani az ya da çok oluşu kadar niteliği de yani içsel veya dışsal oluşu da önemlidir. İçsel ve dışsal motivasyonu şu şekilde açıklamak mümkündür.

Dışsal motivasyon; eğer bir davranış elle tutulur bir ödül sağlamak için yapılıyorsa bu aktivitenin nedeni dışsal motivasyondur (Vallerand et al., 1992). Dışsal motivasyon kişinin bir davranışı elde edebileceği bir sonuç için gerçekleştirmesidir. Bu davranış, yaparken keyif almak için değil davranışın sonunda ulaşmak istediği sonuç için gerçekleşir. Deci ve Ryan $(1985 ; 2000)$ daha sonraları dışsal motivasyonu dört farklı gruba ayırmışlardır; dışsal motivasyon-düzen, dışsal motivasyon-kendini ispat, dışsal motivasyon-tanınma ve dışsal motivasyon-bütünleşmedir. Ryan ve Deci (2000) dışsal motivasyondüzenden, dışsal motivasyon-bütünleşmeye doğru motivasyon daha fazla içselleştiğini belirtmişlerdir.

İçsel motivasyon; eğer bir aktivite, aktivitenin doğal olarak sağladığı memnuniyet duygusu için yapılıyorsa nedeni içsel motivasyondur (Vallerand et al., 1992). Bireyin bir etkinliği tamamen içsel doyum elde etmek için gerçekleştirmesidir. İçsel doyumun kaynağı birey için davranışın ilginç ve eğlenceli olmasıdır. Tıpkı Deci ve Ryan'ın (1985) dışsal motivasyonu dört türe ayırması gibi, daha 
sonraki yıllarda içsel motivasyon da Vallerand ve arkadaşları (1992) tarafindan üç türe ayrılmıştır. Bunlar sırasıyla; içsel motivasyon-bilme, içsel motivasyon-başarma ve içsel motivasyon-harekettir.

Özerklik Teorisinde motivasyonun psikolojik iyi oluşu, öğrenmeyi ve etkili performans göstermeyi etkilediği için düzeyinden çok türünün ve niteliğinin önemli olduğunu vurgulanır (Deci, Ryan, 2010a; Deci, Ryan, 2010b). Ancak hangi davranışların içsel motivasyon nedeni ile gerçekleştiğini söylemek oldukça zordur. Çünkü bir kişi için bir davranış içsel motivasyona bağlı olarak gerçekleşirken, başka birey için içsel motivasyona bağlı olarak gerçekleşmeyebilir (Deci, Ryan, 2010a; Deci, Ryan, 2010b). İçsel motivasyonda, davranış sonrası dışardan gelen ödüller ve davranışı gerçekleştirmeye yönelik baskılar önemli değildir. Birey davranışı özgür olarak tercih eder. Kişiler doğduğu andan itibaren içsel motivasyonla davranışlarda bulunurlar. Dışsal pekiştirmelere ihtiyaç duymadan merak ve keşfetme duygularıyla davranırlar. İçsel motivasyonun neden olduğu bu davranışlar insanın gelişiminde oldukça önemlidir. Çevre bu üç gereksinimin giderilme derecesine bağlı olarak içsel motivasyonu güçlendirir ya da zayıflatır (Deci ve Ryan, 2000; Wentzel, Miele, 2009). İçsel motivasyonla sergilenen davranışlar çocukluk döneminde daha çok iken zamanla sosyal kurallara uyulması gerektiğinden azalır, birey kendisine çok ilginç gelmeyen davranışları da sergilemek zorunda kalır. Böylece içsel motive davranışlardan çok, ödül elde etmek veya cezadan kaçınmak için davranışlarda bulunmaya başlar. $\mathrm{Bu}$ davranışlar daha sonra dışsal motivasyonun temelini oluşturur. Dolayısıyla dışsal motivasyon kontrollüdür, birey davranışı sergilemek için baskı hisseder. Fakat bu teoriye göre dışsal nedenler daha sonra içselleştirilebilir. Sonuçta bireyler doğuşta kendilerine ilginç gelmeyen ancak sosyal yaşamda etkili olduğunu gördükleri davranışları zamanla içselleştirerek, içsel motive olurlar. Bu süreç yaşam boyu sürekli olarak sosyal değerlerin içselleştirilmesini sağlar (Deci, Ryan, 2010a; Deci, Ryan, 2010b). Dolayısıyla içselleştirme sürecinin gelişimsel açıdan önemli olduğu söylenebilir. İçsel ve dışsal motivasyonu ayırarak yapılan çalışmalarda içsel motive olan bireylerin bazı farklılıkları tespit edilmiştir. İçsel motive olan bireyler çok farklı stratejiler kullanabilmekte ve akademik olarak daha iyi performans göstermektedir. Yapılan çalışmalarda bu kişilerin aynı zamanda yaşamsal aktivitelerden daha fazla tatmin oldukları ve psikolojik yapılarının da daha iyi olduğu belirlenmiştir (Grolnick ve Ryan 1989; Miserandino, 1996; Ryan ve Deci, 2000). İçselleştirme sürecinin sosyal çevre içinde gerçekleşmesi sosyal çevrenin ve sosyal yönden ilişkili olmanın önemini göstermektedir.

Özerklik Teorisi temel alınarak motivasyon düzeyini belirlemeye yönelik olarak "Academic Motivation Scale" (Vallerand ve ark., 1992) adıyla geliştirilmiş ve Türkçe'ye "Akademik Motivasyon Ölçeği”" olarak uyarlanmıştır (Ünal-Karagüven, 2012). Aynı şekilde Özerklik Teorisi temel alınarak "Needs for Relatedness Scale" (NRS-10) (Richer, Vallerand, 1998) adıyla bir ölçek daha geliştirilmiştir. Bu ölçeğin de Türkçeye adaptasyonu gerekli olmuştur. Adaptasyon ya da diğer bir deyişle uyarlama çalışmaları, yeni bir ölçek geliştirmeye göre daha kısa sürede gerçekleşir. Ayrıca adaptasyon yoluyla hazırlanan ölçekler ile elde edilen veriler başka kültürlerle karşılaştırma yapmaya ve tarafsız değerlendirmeye olanak sağlar, kültürler arası adaptasyon ve değerlendirmelere standartlar getirir (Hambleton, Merenda ve Spielberger, 2005). Bu çalışmanın amacı, adaptasyon yoluyla sosyal ilişki gereksinimi düzeyini belirlemeye yönelik olarak geliştirilmiş bir ölçek olan SİGO-10 ölçeğini Türkçeye kazandırmaktır. Ölçek Türkçe çalışmalarda veri toplamak amacıyla kullanılabilir.

\section{YÖNTEM}

Çalışmada ilişkisel tarama modeli kullanılmış. Önce, orijinal İngilizce ölçeği geliştiren ekip ile iletişim kurulup, gereken izin alınmış daha sonra çalışma iki aşamada gerçekleştirilmiştir. Birinci aşamada Türkçeye çeviri işlemi İngilizce bölümü öğretim üyelerinin yardımı ile üç farklı kişi tarafından gerçekleştirilmiş, bu çevirilerden tek bir form oluşturulmuştur. Anadili İngilizce olan bir öğretim üyesi tarafından Türkçe form tekrar İngilizceye çevrilerek, geri çeviri işlemi yapılmıştır. Dil eşdeğerliği için Yabancı Diller, İngilizce bölümü son sınıf öğrencilerine önce İngilizce formlar verilmiş, iki hafta aradan sonra aynı gruba Türkçe formlar verilerek veri toplama işlemi gerçekleştirilmiştir. İkinci aşamada, geçerlik ve güvenirlik çalışmasına geçilmiştir. Uygulamalar sınıf ortamında yapılmış, katılım gönüllü olmuştur. Tamamlama için her öğrenciye yeterli süre sağlanmıştır. 


\section{1. Çalışma Grubu}

Çalışma grubu İstanbul'da, Marmara Üniversitesi, Göztepe Yerleşkesinde öğrenim görmekte olan öğrencilerin oluşturduğu iki farklı gruptan oluşmuştur. Eğitim Fakültesi, İngilizce bölümü son sınıfta okuyan ve 90 öğrenciden oluşan birinci grup ile dil eşdeğerliği ön çalışması yapılmış daha sonra 300 kişilik ikinci gruba ulaşılmıştır. İlk gruptan elde edilen veriler ikinci grup ile birlikte kullanılmış ve toplamda 390 üniversite öğrencisi çalışma grubunu oluşturmuştur. Çalışma grubunun demografik özellikleri Tablo 1 de verilmiştir.

\begin{tabular}{|c|c|c|c|}
\hline \multicolumn{4}{|c|}{ Tablo 1. Çalışma Grubunun Demografik Özellikleri } \\
\hline & & $\mathbf{f}$ & $\%$ \\
\hline \multirow[t]{3}{*}{ Cinsiyet } & $\mathrm{K} 1 \mathrm{z}$ & 223 & 57,2 \\
\hline & Erkek & 167 & 42,8 \\
\hline & Toplam & 390 & 100 \\
\hline \multirow{6}{*}{ Yaş } & 21 & 31 & 7,9 \\
\hline & 22 & 88 & 22,5 \\
\hline & 23 & 73 & 18,7 \\
\hline & 24 & 107 & 27,5 \\
\hline & 25 & 91 & 23,4 \\
\hline & Toplam & 390 & 100 \\
\hline \multirow[t]{5}{*}{ Bölüm } & Teknik Eğitim Fakültesi & 184 & 47,1 \\
\hline & Atatürk Eğitim Fakültesi & 90 & 23,1 \\
\hline & Hukuk Fakültesi & 60 & 15,4 \\
\hline & İlahiyat Fakültesi & 56 & 14,4 \\
\hline & Toplam & 390 & 100 \\
\hline \multirow[t]{3}{*}{ Sinıf } & 3 & 114 & 29,2 \\
\hline & 4 & 276 & 70,8 \\
\hline & Toplam & 390 & 100 \\
\hline
\end{tabular}

Grupta $223(\% 57,2)$ kız ve $167(\% 42,8)$ erkek öğrenci yer almıştır. Yaş ortalaması 22 olup, yukarıdaki Tablo 1'de görüldügü gibi dağılım 20-28 yaşlar arasındadır. Çalışma grubunu oluşturan öğrenciler dört farklı fakültenin öğrencileridir. Çalışma grubu üçüncü ve dördüncü sinıf öğrencileri ile sinırlandırılmıştır.

\subsection{Veri Toplama Araçları}

Öğrencilerden, demografik verileri toplamak için araştırmacı tarafindan on sorudan oluşan bir anket hazırlanmış ve bu anket ölçeklerin en başında yer almıştır. Anket formu açık ve kapalı uçlu sorulardan oluşmuştur. Her öğrenci için, başında anket formunda yer aldığı SİGÖ ile birlikte ÇDÖ-10den oluşan üçlü bir set hazırlanmıştır.

2.2.1. Sosyal İlişki Gereksinimi Ölçeği (SİGÖ-10): SİGÖ-10, Richer ve Vallerand (1996) tarafindan Özerklik Teorisi (Self-Determination Theory) (Deci ve Ryan, 1985; 2000) temelinde geliştirilen bir ölçektir. Orijinal form İngilizce olarak Kanada'da "The Need for Relatedness Scale" (NRS-10) adıyla geliştirilmiştir (Richer, Vallerand, 1998). Bu ölçek, insanların okul, iş yeri, spor takımı gibi farklı ortamlarda sosyal ilişki düzeylerini değerlendirir. Farklı yaşam alanlarında hatta genel olarak hayatın her alanında kullanmak mümkündür. Bu durumda yapılması gereken sadece ölçeğin başındaki yönergeyi uygulama alanına (örneğin: okul ve iş yeri gibi) uygun bir şekilde değiştirmektir. Ölçek 10 maddeden oluşur. Bu 10 maddenin 5 tanesi (1,3,5,7,9 numaralı maddeler) "samimiyet" (acceptance-kabul), 5 tanesi (2,4,6,8,10 numaralı maddeler) "yakınlı" (intimacy) boyutuna aittir. Her madde 7 dereceli bir ölçekte değerlendirilir. İfadelerin tamamı listenin başında bulunan cümleyle birleştirilerek değerlendirilmesi gerekir. Uygulama ifadelilerin devamında yer alan 1 (kesinlikle katılmıyorum) ile 7 (kesinlikle katılıyorum) arasında yedi derece üzerinde işaretleme yapılarak gerçekleşir. Örneğin: İş arkadaşlarımla olan ilişkilerimde kendimi ........ hissediyorum. "1. Desteklenmiş ....." "2. Onlara yakın ... ." $\mathrm{Bu}$ çalışmada ulaşılan NRS-10'a ait Cronbach alfa değeri 0.92 düzeyindedir. 
2.2.2. Çevresel Destek Ölçeği (ÇDÖ): Daha önce sosyal güç veya destek (Pearlin, Lieberman, Menaghan ve Mullan, 1981) ve öz-yeterlik (Schwarzer, 1993) konularında geliştirilmiş ve yaygın olarak kullanılmakta olan iki ölçek geliştirilmiştir. Daha sonra bu iki ölçekten yola çıkılarak Hobfoll, Jackson ve arkadaşları (2002) tarafından Communal Mastery Scale (CMS) adıyla geliştirilmiş olan bir ölçektir. Çevresel destek ölçeği olarak Türkçeleştirilmiştir (Ünal-Karagüven, 2005). On maddeden oluşmaktadır. Başlangıcında kısa bir yönerge bulunan ölçekte bireyin her bir ifadeyi 1 (kesinlikle katılmıyorum) ile 4 (kesinlikle katılıyorum) arasında değerlendirerek, ifadenin devamında dört derece üzerinde işaretlemesi istenir. Ölçekte örneğin; "Ailem ve arkadaşlarımla birlikte problemlerimin çoğunu çözebilirim.", "Yakınlarımın yardımı sayesinde hayatımı daha çok kontrol edebilirim.", veya "Kendi hedeflerime başkalarının hedeflerine ulaşmalarına yardım ederek ulaşabilirim." gibi ifadeler yer alır (Hobfoll, Schröder ve ark., 2002). Bu çalışmada ÇDÖ’ye ait Cronbach alfa değeri 0.71 düzeyindedir.

\section{BULGULAR}

Dil eşdeğerliği çalışmasında önce ölçeğin orijinal İngilizce formları İngilizce bölümü son sınıf ögrencilerine uygulanmıştır. Sonuçta $1,3,5,7$ ve 9. maddelerden oluşan samimiyet (intimacy) alt boyutunun 0.867 ve 2, 4, 6, 8 ve 10 uncu maddelerden oluşan Yakınlık Duyma (relatedness) alt boyutunun 0.863 düzeyinde Cronbach alfa değerlerine ulaşılmıştır. Tüm testin ise Cronbach alfa değerleri 0.917 düzeyinde Bu durum SİGÖ’nin orijinal İngilizce ölçeğinin Türk öğrenciler tarafindan anlaşılabilir olduğunu göstermiştir. Aynı gruba yaklaşık iki hafta sonra Türkçe formlar verilmiş ve korelasyon değerleri hesaplanmıştır aşağıdaki Tablo 2'de verilmiştir.

\begin{tabular}{|c|c|c|c|c|}
\hline$\overline{\mathbf{N}}$ & Alttestler & $\mathbf{n}$ & $\mathbf{R}$ & Cronbach Alfa \\
\hline \multirow{3}{*}{99} & Samimiyet (Acceptance) & 5 & $.469 * *$ & 0,867 \\
\hline & Yakınlık (Intimacy) & 5 & $.544 * *$ & 0,863 \\
\hline & İGÖ-Tümtest (relatedness) & 10 & $.492 * *$ & 0,917 \\
\hline
\end{tabular}

$\mathrm{N}=$ Denek sayısı, $\mathrm{n}=$ Ölçekteki madde sayısı, ${ }^{* *} p \leq .01$

Tablo 2'de görüldüğü gibi ölçek ve alt ölçeklere ait korelasyonlar $0.47(p \leq .01)$ ile $0.77(p \leq .01)$ arasında değişmektedir. Aşağıdaki Tablo 3'de ise maddeler arası korelasyonlar verilmiştir.

\begin{tabular}{ll}
\hline \multicolumn{2}{l}{$\begin{array}{l}\text { Tablo 3. Türkçe ve Ingilizce Uygulamalardan Elde } \\
\text { Edilen Puanlarda Maddeler Arasindaki } \\
\text { Korelasyonlar }\end{array}$} \\
\hline Maddeler & $(\mathbf{r})$ \\
\hline 1. & $.391^{* *}$ \\
\hline 2. & $.517^{* *}$ \\
\hline 3. & $.647^{* *}$ \\
\hline 4. & $.509^{* *}$ \\
\hline 5. & $.596^{* *}$ \\
\hline 6. & $.590^{* *}$ \\
\hline 7. & $.403^{* *}$ \\
\hline 8. & $.652^{* *}$ \\
\hline 9. & $.439^{* *}$ \\
\hline 10. & $.356^{* *}$ \\
\hline $\mathrm{N}=99, * *$ & $p \leq .01$
\end{tabular}

Tablo 3'de görüldüğ̈̈ gibi Türkçe ve İngilizce formlara ait maddeler arası korelasyonlar 0.39 ( $p \leq .01)$ ile $0.64(p \leq .01)$ arasında değişmektedir. Bu bulgular NRS-10 ile SİGÖ arasında benzerlik olduğunu göstermiştir.

\section{1. Geçerlik}

SİGÖ uygulamasından elde edilen puanlar, kişinin iş veya sınıf ortamında çevresindeki bireylerle 
arkadaşlık düzeyinin göstergesidir. Elde edilen puanların doğruluğu kuramsal veya kavramsal (construct) geçerlik yöntemiyle sınanmıştır. Bu amaçla ölçüt bağımlı geçerliği yöntemi kullanılmış, SİGÖ’nin diğer ölçeklerle olan ilişkilerine bakılmıştır. Yapı geçerliğini sınamak için faktör analizi tekniğinden yararlanılmıştır. Kapsam geçerliği için uzman görüşü alınmıştır. Ölçüt bağımlı geçerlik için ÇDÖ-10 kullanılmıştır. SIGGÖ ile aynı gruplara uygulanan ÇDÖ-10'un toplam puanları arasındaki korelasyonlar Tablo 4'te verilmiştir.

Tablo 4. SIGÖ Alttestleri ile ÇDÖ-10Arasındaki Korelasyonlar

\begin{tabular}{lllll}
\hline Alttestler & $\begin{array}{l}\text { SiGÖ } \\
\text { Samimiyet }\end{array}$ & $\begin{array}{l}\text { SíGÖ } \\
\text { Yakınlık }\end{array}$ & $\begin{array}{l}\text { SIGGÖ } \\
\text { Toplam }\end{array}$ & ÇDÖ-10 \\
\hline $\begin{array}{l}\text { SİGÖ } \\
\text { Samimiyet }(n=5)\end{array}$ & - & & \\
\hline $\begin{array}{l}\text { SİGÖ } \\
\text { Yakılık }(n=5)\end{array}$ & $.875^{* *}$ & - & \\
\hline $\begin{array}{l}\text { SİGÖ } \\
\text { Toplam }(n=10)\end{array}$ & $.965^{* *}$ & $.963^{* *}$ & - \\
\hline $\begin{array}{l}\text { ÇDÖ-10 } \\
(n=20)\end{array}$ & $.101^{*}$ & $.109^{*}$ & $.103^{*}$ & - \\
\hline
\end{tabular}

Tablo 4'de görüldüğ̈̈ gibi ÇDÖ-10 ile samimiyet arasında 0,101, yakınlık arasında 0,109 , toplam puan ile 0,103 pozitif yönde anlamlı ilişki belirlenmiştir. Ayrıca tablo 4 'te SİGÖ alt ölçekler arasında da .875 ile .965 arasında anlamlı ilişkiler gösterdiği göstermektedir. Ulaşılan bu değerler ölçeğin kavramsal geçerliği için kanıt niteliğindedir.

SİGÖ’nin ayırt ediciliğini sınamak için yapılan hipotez testi sonuçlarında; cinsiyet farklılığının, bulunduğu bölümden memnun olmanın ve annenin çalışıyor olmasının ortalamaları etkilediği bulunmuştur. T-test sonuçlarına göre erkeklerin puan ortalamaları hem iki alt boyutta hem de toplam puanda kızlardan daha yüksektir; samimiyet: $(\mathrm{t}=-2.31, \mathrm{sd}=6.49, \mathrm{p}<.05)$, yakınlık: $(\mathrm{t}=-2.65, \mathrm{sd}=6.48$, $\mathrm{p}<.05)$ ve toplam puan: $(\mathrm{t}=-2.12, \mathrm{sd}=12.66, \mathrm{p}<.05)$. Bulunduğu bölümden memnun olan öğrenciler ile olmayanlar arasında t-test sonuçlarına göre alt ölçek ortalamaları arasında anlamlı farklılık bulunmuştur; samimiyet: $(\mathrm{t}=2.70, \mathrm{sd}=5.52, \mathrm{p}<.01)$, yakınlık: $(\mathrm{t}=2.09, \mathrm{sd}=5.86, \mathrm{p}<.05)$, toplam puan: $(\mathrm{t}=2.47, \mathrm{sd}=10.82$, $\mathrm{p}<.05)$. Annesi çalışanların her boyutta ortalamaları çalışmayanlardan daha yüksektir; kabul: $(\mathrm{t}=-1.79$, $\mathrm{sd}=4.91, \mathrm{p}<.05)$, yakınlık: $(\mathrm{t}=-2.77, \mathrm{sd}=5.74, \mathrm{p}<.01)$, toplam puan: $(\mathrm{t}=-2.40, \mathrm{sd}=10.20, \mathrm{p}<.05) . \mathrm{Bu}$ sonuçlar ölçeğin ayırt ediciliği özelliğini kanıtlamaktadır.

Yapı geçerliğini sınamak için faktör analizi yapılmıştır. Türkçeleştirilmiş ölçeğin orijinal ölçekteki gibi iki boyutlu olup olmadığını anlamak, faktör yapısını değerlendirmek için principal faktör tekniği ile varimax rotasyonu kullanılarak açımlayıcı (exploratory) faktör analizi ile SİGÖ’nün boyutları araştırılmıştır.

Faktör analizinde denek sayısının büyüklüğü önemlidir. Bu nedenle önce denek sayısının uygunluğunu test eden "KMO ve Bartlett's Test" yapılmıştır. Sonucun istatistik olarak anlamlı olması değişkenler arasında ilişki olduğunu, 1'e yakın olması ise faktör analizi yönteminin bu grup için kullanılabileceğini gösterir, 0.5 ten küçük olması durumunda daha fazla veri toplanması gerekir (Tonta, 2008). Analiz sonucunda ulaşılan KMO değerinin $0.833(p \leq .001)$ düzeyinde ve anlamlı olması denek sayısının yeterli olduğunu ve değişkenler arasında ilişki olduğunu göstermiştir. Maddelerin kaç faktörde toplanacağını görmek için Varimax döndürme tekniği kullanılmıştır. Sonuçlar Tablo 5'te verilmiştir. 
Tablo 5. SIGGÖ Maddelerinin Faktör Yükleri, Ortak Faktör Varyanslarl (Communalities) (h2), Ortalama (X) ve Standard Sapmalart (Ss)

\begin{tabular}{lllll}
\hline Maddeler & Faktör 1 & h2 & X & Ss \\
\hline M. 9 & .863 & .745 & 5,187 & 1,510 \\
M. 2 & .857 & .735 & 5,279 & 1,423 \\
M. 7 & .851 & .724 & 5,289 & 1,360 \\
M. 6 & .830 & .690 & 4,841 & 1,646 \\
M. 10 & .811 & .657 & 5,561 & 1,497 \\
M. 5 & .796 & .634 & 5,225 & 1,235 \\
M. 8 & .767 & .588 & 5,164 & 1,456 \\
M. 3 & .753 & .567 & 4,705 & 1,319 \\
M. 1 & .691 & .478 & 4,759 & 1,602 \\
M. 4 & .680 & .462 & 4,533 & 1,702 \\
\hline
\end{tabular}

Açıklanan Varyans:

Toplam : \%62,78

Faktör 1: \%62,78

Tablo 5'te göründüğ̈ gibi SİGÖ'ye ait 10 madde döndürmeden sonraki toplam varyansın \%62,78'sını açıklayan, özdeğeri (eigenvalue) 1 den büyük tek faktör altında toplanmıştır. Toplam varyansın yüksek olması (\%58.06) ölçeğin tamamının tek bir boyut olarak değerlendirilebileceğini göstermiştir.

\section{2. Güvenirlik}

Türkçeleştirilmiş form olan SİGÖ'nun güvenirliği, homojenlik ve içtutarlık sinanarak saptanmıştır. Ölçek maddelerinin içtutarlığı Kuder Richardson 20 (KR 20) formülünün genelleştirilmiş formu olan Cronbach alfa değerleri ile belirlenmiştir. Tablo 6'da SİGÖ'nun alt testlerinin korelasyon değerleri, Cronbach alfa, ortalama ve standart sapma değerleri verilmiştir.

Tablo 6. SIGÖ ve Alttestler Arasindaki Korelasyonlar, KR 20 Alfa, Ortalama $(X)$ ve Standart Sapma (SS) Değerleri

\begin{tabular}{|c|c|c|c|c|c|c|}
\hline Alttestler & $\begin{array}{l}\text { SİGÖ } \\
\text { Samimiyet }\end{array}$ & $\begin{array}{l}\text { SİGÖ } \\
\text { Yakınlık }\end{array}$ & $\begin{array}{l}\text { SİGÖ } \\
\text { Toplam }\end{array}$ & Alfa & $\mathbf{X}$ & S.S. \\
\hline SİGÖ & - & & & .88 & 25,16 & 5,78 \\
\hline $\begin{array}{l}\text { Samimiyet }(\mathrm{n}=5) \\
\text { SİGÖ } \\
\text { Yakınlık }(\mathrm{n}=5)\end{array}$ & $.647^{* *}$ & - & & .88 & 25,37 & 6,34 \\
\hline $\begin{array}{l}\text { SIGÖ } \\
\text { Toplam }(n=10)\end{array}$ & $.613^{* *}$ & $.658^{* * *}$ & - & .93 & 50,54 & 11,63 \\
\hline
\end{tabular}

Tablo 6'da görüldüğü gibi alttestlere ait korelasyon değerleri; 0.613 ile 0.658 arasında ve pozitif yönde anlamlıdır $(p \leq .01)$. Cronbach alfa değerleri ise 0.88 ile 0.93 arasında değişmektedir. Orijinal ölçeğin uygulamasından elde edilen değer ise 0.87 olarak belirlenmiştir. Bu durum her iki formun benzer olduğunu işaret etmektedir. Tümteste ait Cronbach alfa değeri (0.93), ölçeğin genel içtutarlık ve benzeşiklik düzeyinin tatminkâr olduğunu göstermiştir. Maddelerin içtutarlığı ve geçerliği hakkında ayrıntılı bilgi madde-toplam puan (madde bırakma) korelasyonlarından çıkarılmıştır. Ulaşılan değerler Tablo 7'de verilmiştir. 


\begin{tabular}{|c|c|c|}
\hline Maddeler & Alttestler & Tümtest \\
\hline & SİGÖK & $\begin{array}{l}\text { SIGÖ } \\
\text { (TOPLAM) }\end{array}$ \\
\hline 1 & .62 & .62 \\
\hline 3 & .70 & .68 \\
\hline 5 & .75 & .73 \\
\hline 7 & .76 & .79 \\
\hline 9 & .73 & .81 \\
\hline \multicolumn{3}{|c|}{ SİGÖYD } \\
\hline 2 & .74 & .81 \\
\hline 4 & .61 & .62 \\
\hline 6 & .80 & .78 \\
\hline 8 & .69 & .71 \\
\hline 10 & .70 & .76 \\
\hline
\end{tabular}

Yukarıdaki Tablo 7'de görüldüğ̈̈ gibi madde-alttest korelasyonları 0.61 ile 0.80 , madde-toplam puan korelasyonları ise 0.62 ile 0.81 arasındadır. Korelasyonların tamamı pozitif yöndedir. Başka bir güvenirlik göstergesi olarak alttest puanlarına ve toplam puanlara ait Ölçmenin Standart Hatası hesaplanmıştır. Özellikle, bireysel puanların değerlendirilmesinde kullanılan ölçmenin standart hatası tekniği ile elde edilen değerler Tablo 8'de verilmiştir.

\begin{tabular}{lc}
\hline \multicolumn{2}{l}{ Tablo 8. Alttestlere Ait Standart Hata Değerleri } \\
\hline Alttestler & Sh \\
\hline SİGÖK & 4.20 \\
SİGÖYD & 4.28 \\
SİGÖ Toplam & 7.08 \\
\hline
\end{tabular}

Tablo 8'de görüldüğü gibi Türkçeleştirilmiş formunda alttestlerin standart hatası 4.20 ile 4.28 puan arasında değişmektedir. SİGÖ alttestlerinden elde edilen değerler yaklaşık olarak 4 puan farklılık gösterebilir. Toplam puan ise 7 puanlık fark gösterebilir.

\section{SONUÇ VE TARTIŞMA}

$\mathrm{Bu}$ çalışmada bireylerin farklı ortamlardaki sosyal ilişki gereksinimi düzeyini belirlemek amacıyla geliştirilen bir ölçeğin Türkçeye adaptasyonuna yönelik bulgular değerlendirilmiştir. Ölçek Özerklik Teorisi temelinde geliştirilmiş bir ölçek olduğu için öncelikle Özerklik Teorisini açıklamak gerekli olmuştur. Daha sonra adaptasyon çalışmasına geçilmiştir.

Ölçeğin Türkçe ve İngilizce formları arsında paralellik olduğu Türkçe ve İngilizce uygulamalardan elde edilen puanlar arasındaki yüksek korelasyonlar ile kanıtlamıştır. Geçerlik sınaması; kapsam geçerliği, kavramsal (uyum) ya da kuramsal geçerliği, hipotez testi yöntemleri ile sınanmış, ölçeğin ayırt ediciliği kanıtlanmıştır. Yapı geçerliğini sınamak için faktör analizi ölçeğin tamamının tek boyut olarak değerlendirilebileceğini göstermiştir. Daha önce Çelik, Baltık ve Özcan (2016) tarafından arkadaşlık ilişkilerini belirlemek amacıyla geliştirilen 16 maddelik bir ölçeğin üç boyutlu olarak tespit edilmesinin madde sayısından kaynaklandığı düşünülmüştür. Bu çalışmada çalışılan ölçeğin orijinali iki boyutlu olmasına rağmen burada tek boyutlu çıkmasının bir nedenin kültürel farklılık olarak düşünülebilir. Kanada kültüründe iki boyutlu geliştirilen bir ölçekteki ifadeler, farklı bir kültürde birbirine yakın olarak görülerek tek boyut altında toplanabilir şeklinde yorumlanmıştır. SİGÖ-10 iki boyutlu olmanın yanında tek boyutlu olarak kullanılabilir.

SİGÖ’nun güvenirliği, homojenlik ve içtutarlık sınaması şeklinde yapılmış bulgular içtutarlık ve benzeşiklik düzeyinin tatminkâr olduğunu göstermiştir. Ölçmenin Standart Hatası alt boyutlara ait puanlarda 4 puan toplamda ise 7 puan farkl1lık olabileceğini göstermiştir. Sonuç olarak; SíGÖ-10'un Türk toplumu için geçerli ve güvenilir olduğu belirlenmiş, yeterli psikometrik değerlere ulaşılarak ölçek 
Türkçeye adapte edilmiştir. Türkçe çalışmalarda sosyal ilişki gereksinimini belirlemek amacıyla kullanılabilir. Çalışmanın güçlü ve zayıf olduğu noktaları değerlendirmek gerekirse, SİGÖ ile birlikte kullanılan ölçeklerin ve yöntemlerin standart olması, ayrıca çalışma grubunun büyüklüğü, çalışmanın güçlü olduğu önemli noktalardır. Zayıf olduğu noktalar diğer çalışmalarla benzerlik göstermektedir. Örneğin; çalışma grubunun aynı üniversitenin öğrencileri ile sınırlı olmasıdır. Daha geniş bir evrenden oluşturulacak örneklem gruplarından elde edilen veriler ile ölçeğin geçerlik ve güvenirliği tekrar sınanabilir. Bu nedenle, ölçeğin Türkçe formunun geçerlik ve güvenirliğini artırmak ve ulaşılan değerleri güncellemek için benzer çalışmaların yapılması önerilmiştir.

Bilgilendirme / Acknowledgement: Bu çalışma, İstanbul'da gerçekleştirilen XX. Ulusal Eğitim Bilimleri Kongresinde poster bildiri olarak sunulmuștur.

\section{KAYNAKÇA}

Alderfer, C. P. (1972). Existence, relatedness, and growth: Human needs in organizational settings. New York, NY, US: Free Press.

Çelik, B. S., Batık, M. V. ve Özcan, K. (2016). Arkadaşlık ilişkilerinde kalıp yargılar ölçeği: Geçerlik ve güvenirlik çalışması. Electronic Turkish Studies, 11(19), 133-144.

Beyazkürk, D., Anlıak, Ş. ve Dinçer, Ç. (2007). Çocuklukta akran ilişkileri ve arkadaşl1k. Eurasian Journal of Educational Research (EJER), 26(1), 13-26.

Connell, J. P. and Wellborn, J. G. (1991). Competence, autonomy and relatedness: A motivational analysis of self-system processes. In M. Gunnar and L. A. Sroufe (Eds.), Minnesota Symposium on Child Psychology: Vol. 23. Self-processes in development (pp. 43-47). Chicago: University of Chicago Press.

Deci, E. L. and Ryan, R. M. (2002). Handbook of self-determination research. Rochester: University of Rochester Press.

Deci, E. L. and Ryan, R. M. (2010). Self-determination. UK: John Wiley and Sons, Inc.

Deci, E. L. and Ryan, R. M. (2010a). Self-determination. The Corsini encyclopedia of psychology, 1-2.

Deci, E. L. and Ryan, R. M. (2010b). Intrinsic motivation. The Corsini encyclopedia of psychology,1-2.

Deci, E. L. and Ryan, R. M. (2014). Autonomy and need satisfaction in close relationships: Relationships motivation theory. In $\mathrm{N}$. Weinstein, Human motivation and interpersonal relationships: Theory, research, and applications. (pp. 53-73). Dordrecht, Netherlands: Springer.

Deci, E. L. and Ryan, R. M. (2016). Optimizing students' motivation in the era of testing and pressure: A self-determination theory perspective. In Building autonomous learners. (pp. 9-29). Singapore: Springer.

Deci, E. L. and Vansteenkiste, M. (2004). Self-determination theory and basic need satisfaction: Understanding human development in positive psychology. Ricerche di Psicologia, 1(27), 23-40.

Grolnick, W. S. and Ryan, R. M. (1989). Parent styles associated with children's self-regulation and competence in school. Journal of Educational Psychology, 81, 143-154.

Hambleton, R. K., Merenda, P. F. and Spielberger, C. D. (2005). Adapting educational and psychological tests for cross-cultural assessment. Mahwah, New Jersey: Lawrence Erlbaum.

Hobfoll, S. E., Jackson, A., Hobfoll, I., Pierce, C. A. and Young, S. (2002). The impact of communalmastery versus self-mastery on emotional outcomes during stressful conditions: A prospective study of Native American women. American Journal of Community Psychology, 30, 853-871. 
Hobfoll, S. E., Schröder, K. E. E., Wells, M. and Malek, M. (2002). Communal versus individualistic construction of sense of mastery in facing life challenges. Journal of Social and Clinical Psychology, 21, 362-399.

Kağıtçıbaşı, C. (2005). Autonomy and relatedness in cultural context: Implications for self and family. Journal of cross-cultural psychology, 36(4), 403-422.

Maslow, A. H. (1943). A Theory of Human Motivation. Psychological Review, 50, 370-396.

Maslow, A. H. (1970). Motivation and personality. 2nd. ed., New York: Harper and Row.

Minnaert, A., Boekaerts, M., and De Brabander, C. (2007). Autonomy, competence, and social relatedness in task interest within project-based education. Psychological Reports, 101(2), 574586.

Miserandino, M. (1996). Children who do well in school: Individual differences in perceived competence and autonomy in above average children. Journal of Educational Psychology, 88, 203-214.

Niemiec, C. P. and Ryan, R. M. (2009). Autonomy, competence, and relatedness in the classroom: Applying self-determination theory to educational practice. School Field, 7(2), 133-144.

Ormrod, E., (2018). Öğrenme psikolojisi. (Çeviri editörü Mustafa Baloğlu). Ankara: Nobel Akademik Yayınc1lik.

Richer, S. and Vallerand, R.J. (1998). Construction and validation of the perceived relatedness scale. Revue Européene de Psychologie Appliquée, 48, 129-137.

Ryan, R. M. and Deci, E. L. (2000). Self-determination theory and the facilitation of intrinsic motivation, social development, and well-being. American Psychologist, 55(1), 68-78.

Ryan, R. M. and Deci, E. L. (2017). Self-determination theory: Basic psychological needs in motivation, development, and wellness. New York: Guilford Publishing.

Ryan, R. M. and Deci, E. L. (2019). Supporting autonomy, competence, and relatedness: The coaching process from a self-determination theory perspective. In S. English, J. M.

Schwartz, S. H. (1994). Are there universal aspects in the structure and contents of human values? Journal of social issues, 50(4), 19-45.

Skinner, E. A. and Belmont, M. J. (1993). Motivation in the classroom: Reciprocal effects of teacher behavior and student engagement across the school year. Journal of Educational Psychology, 85, 571-581.

Tonta, Y. (2008). Faktör analizi. 29 Nisan 2018 tarihinde yunus.hacettepe.edu.tr/ tonta/courses/spring2008/bby208 adresinden erişildi.

Ünal-Karagüven, M. H. (2005, July). Academic motivation and communal mastery of technical high school students. Paper presented at the $25^{\text {th }}$ International STAR Conference, Stress and Anxiety Research Society, Germany.

Ünal-Karagüven, M. H. (2012). Akademik motivasyon ölçeğinin Türkçeye adaptasyonu. Kuram ve Uygulamada Eğitim Bilimleri, 12(4), 2599-2620.

Vansteenkiste, M., Zhou, M., Lens, W. and Soenens, B. (2005). Experiences of autonomy and control among Chinese learners: Vitalizing or immobilizing? Journal of educational psychology, 97(3), 468.

Wahba, M. A. and Bridwell, L. G. (1976). Maslow reconsidered: A review of research on the need hierarchy theory. Organizational Behavior and Human Performance, 15, 212-240

Wentzel, K. R. and Miele, D. B. (2009). Handbook of motivation at school. UK:Routledge. 